\title{
On fitting paradigms to people
}

\author{
A.P. Moerdyk and David A.L. Coldwell \\ Formerly of the National Institute for Personnel Research, Johannesburg
}

\begin{abstract}
In a previous article (Coldwell and Moerdyk, 1981) it was argued that many blacks in South Africa are at a disadvantage in the 'White man's world' of business and industry as a result of a number of cultural factors, some of which were described. In this paper, the suggestion is made that it is probably easier and more cost-effective to find ways in which both tasks and organizations can be restructured along socio-technical design lines, than it is to try to change the personality and value structures of the labour force to fit them to the demands of the work place. A number of cultural differences are outlined and suggestions put forward about possible ways in which jobs and organizations can be modified to make them more compatible with the characteristics of the work force. A closer 'match' between the individual and his work environment is seen as the key to enhanced productivity, reduced stress, and consequent improvements in both job satisfaction and company profitability.
\end{abstract}

S. Afr. J. Bus. Mgmt. 1982, 13: $189-196$

In 'n vorige artikel (Coldwell en Moerdyk, 1981) was dit gestel dat baie swart mense in Suid-Afrika in die 'Witman' se besigheids. en industriẹle wêreld benadeel word as gevolg van 'n aantal kulturele faktore (waarvan sommige beskryf is). In hierdie artikel word voorgestel dat dit waarskynlik makliker en meer koste-effektief is om maniere te vind waardeur take en organisasies in terme van sosio-tegniese ontwerp herstruktureer kan word, eerder as om te poog om die persoonlike en waarde-strukture van die werksmag te verander om aan die eise van die werksomgewing te voldoen. 'n Aantal kulturete verskille word beskryf en voorstelle word gemaak in verband met moontlike maniere waarop betrekkings en organisasies gemodifiseer kan word om groter versoening met die eienskappe van die werksmag te bewerkstellig. 'n Nouer 'pas' tussen die individu en sy werksomgewing word gesien as die sleutel tot verhoogde produktiwiteit, verlaging van spanning en gevolglike verbetering van werksatisfaksie sowel as maatskappy-winsgewendheid.

S.Afr. Tydskr. Bedryfsl. 1982, 13: 189- 196
A.P. Moerdyk and D.A.L. Coldwell

The Chamber of Mines, Human Resource Laboratory, Box 91230

Auckland Park 2006, Republic of South Africa

'To whom correspondence should be addressed
In a recent paper ${ }^{1}$ it was argued that the black worker in South Africa may be at a considerable disadvantage in the business world as a result of a cultural heritage that does not adequately prepare him for the needs of the dominant business ethic. It was argued that, in general terms, blacks operate within a different paradigm or set of assumptions that results in a failure to grasp the central thrust and dynamics of the Western business system. Africa has on the whole tended to prefer more socialistic approaches to capitalistic ones as the former appear to be more in keeping with its cultural heritage.

While it has been argued, for example in Wober, ${ }^{2}$ that it is impossible to generalize about 'the African' or 'African culture', LeVine takes a contrary view and gives evidence for 'strong central tendencies of economy, social structure and culture among African populations' ${ }^{3}$ and further that '... there is the indication of a homogeneity of socioeconomic institutions in subSaharan Africa which suggests a common context of experience for Africans growing up in diverse parts of the continent'. ${ }^{4}$ Van den Berg ${ }^{5}$ and Safavi ${ }^{6}$ also argue for the existence of particular African values and culture.

The purpose of the present paper is to examine the sociocultural and psychological variables that arise from this cultural difference and to suggest ways in which these factors can be utilized or built upon in order to achieve a better utilization of the human resource - a particularly urgent problem in contemporary South Africa.

In looking at the basic dimensions of cultural differences that appear to exist between most blacks and most whites in subSaharan Africa and South Africa in particular, it is argued that these exist across all levels of acculturation and that the general picture painted is as applicable to the highly skilled, urbanized and sophisticated black as it is to the relatively unskilled rural black. MacKay has noted, for example, that

The majority of urbanised blacks' attitudes are still shaped to a greater or lesser extent by their tribal/cultural heritage - if not directly, then indirectly by relatives and their expectations. ${ }^{7}$

As evidence for this point of view, she cites a number of works, ${ }^{8}$ while Van den Berg notes that in general ' . . there are many deep-rooted beliefs, customs and traditions of which the upbringing of youth is one, that resist change and 
are often strengthened in adversity'. 9 (For an examination of the relationships between culture, socialization practices, personality formation, and adult behaviour, see Isaacs, ${ }^{11}$ p.31.) Onyemelukwe argues that this resistance to change occurs because newly acquired skills and behaviour patterns give way at times of stress to behaviours and thinking patterns acquired earlier in life. He notes that

... the process of integrating newly developed habits into a person's pre-existing personality configuration and his increasingly automatic response to such new situations go hand-in-hand . . . [The] value-attitudes of a person are deeply rooted in his childhood and operate almost automatically below the level of consciousness ... and are difficult to extinguish. Even when they have been inhibited, they often reassert themselves when the inhibiting influence is removed or when the new responses cannot adequately cope with the situation. ${ }^{10}$

In the light of the above arguments, it is felt that generalizations about 'blacks' and 'whites' can be made and that while urbanization and other processes of acculturation undoubtedly change values, beliefs and attitudes in the direction of those held by whites, such original values, beliefs and attitudes are nevertheless fairly robust and resistant to change across time and circumstance. This would appear to be the case because they are acquired early in the individual's development, and thus constitute the core of his belief structure.

\section{Some cultural differences between blacks and whites}

Perhaps the most striking differences to emerge in a comparison of the socio-cultural attitudes that exist between the Third World (undeveloped, under-developed, developing, least-developed) countries and the industrialized (developed, modern) countries are those related to socialization practices: where the former cultures tend to emphasize collectivism or communalism, the latter stress the importance of individualism. While the white child is typically socialized into patterns of early independence, self-responsibility, and competitive materialism, " the black child in Africa is generally reared into patterns of group awareness, shared responsibility and the need to preserve and foster communal bonds - especially family and tribal bonds. ${ }^{a}$ Gordon and Goduka $^{12}$ in a study on child rearing attitudes note that most black family heads in an urban setting (Soweto) stress the importance of obedience, compliance to community norms and respect for elders as desirable values in their children. However, black ministers of religion expressed the wish for their children to become selfassertive and autonomous 'problem-solvers'. Thus there does appear to be some movement away from traditional values in this particular group.

Berry, ${ }^{13}$ in accounting for the origin and maintenance of particular social and cultural practices, has put forward an ecological model in terms of which the cultural values and behaviours are determined by environmental factors and the demands these place upon the individual and the society for

\footnotetext{
'As with all generalizations, there is no such thing as 'the Black', or 'the White', nor is the equation of blacks with 'traditional' and whites with 'modern' satisfactory: both are unwarranted simplifications.
}

their continued existence. These needs determine such factors as child-rearing practices and these in turn give rise to fairly well-defined psychological characteristics and competencies in terms of which the individual structures and experiences his world. It is for this reason that personality and culture generally covary with each other. ${ }^{14}$

Some of the more important social and psychological variables that seem to covary and to distinguish between 'modern' and 'traditional' societies are listed in Table 1.

If we examine the variables listed in Table 1, particularly those in the lower half of the table, it becomes apparent that the 'modern' individual possesses a number of characteristics not possessed by the 'traditional' person and which are considered to be important for success by the Western-oriented business system that is currently operating in South Africa. ${ }^{b}$ In general terms, the information presented in Table 1 points to a mismatch between the environmental demands of the business system which requires 'modern' personnel, and the available manpower which in South Africa is still largely 'traditional', in terms of the dimensions described. It has been argued elsewhere, for example by Van Harrison, ${ }^{15}$ that a major symptom of this kind of person-environment ( $P$ E) mismatch is a high level of stress but it also manifests itself in other areas such as low productivity, high turnover rates, high accident rates and a number of other symptoms of industrial ill-health, all of which characterize the South African business scene to a greater or lesser extent. As Sanford has noted, albeit in a very different context:

An environment must be suited to the species; if it is not, the organism dies or goes elsewhere. ${ }^{16}$

An example of such a mismatch would be the case where a flexible, democratic individual was employed in a highly authoritarian organization. Such a person would be likely to experience far more stress and discomfort than he would in a more democratic organization, or a more authoritarian individual would in the authoritarian system. Similarly, in a system that demands individualism, competitiveness and personal responsibility, the individual who has been socialized into patterns of shared responsibility, co-operation and non-competitiveness will be at a distinct disadvantage, will underproduce relative to his real potential and will be seen as a failure by the organization's management.

\section{Ways of increasing person-environment fit}

By presenting the problem in terms of a P-E mismatch, two broad strategies for improvement are suggested. In the first instance (and this is the method used most widely in South Africa) attempts are made to fit the individual more closely to the demands of his work environment - either by selecting individuals with the 'right' attributes or by training him until he acquires these attributes. An example of this approach was given at a recent seminar on Black Advancement held in Pretoria under the auspices of the UNISA School for Business Leadership (July 7-8, 1981) where much emphasis was placed on overcoming the gaps left by poor education, by poor socio-economic background and

\footnotetext{
'The term 'non-traditional' is used here with reference to the norms and practices of the Industrialized World - in many respects the structures suggested are quite 'traditional' from a Third World point of view.
} 
Table 1 Social structure and psychological consequence

\begin{tabular}{|c|c|c|c|}
\hline & Dimension & Modern & Traditional \\
\hline \multirow{12}{*}{ 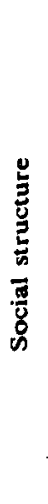 } & Subsistence mode & Industrial/Technological & Agricultural \\
\hline & Use of technology & Widespread & Limited \\
\hline & Rate of technological change & Rapid & Slow \\
\hline & Family structure & Nuclear & Extended \\
\hline & Status & Earned & Ascribed \\
\hline & Source of authority & Ability & Seniority \\
\hline & Occupational mobility & Relatively high & Low \\
\hline & Ambition & Materialistic & Religious, other wordly \\
\hline & Social control & Legal, written & Tradition, cultural \\
\hline & Affiliation and loyalty & Larger unit - nation, employer & Smaller unit - family, tribe, work team \\
\hline & Socialization & Benign, tolerant & Harsh, authoritarian \\
\hline & Basic orientation & Inner directed, individualistic & Other directed, communalistic \\
\hline \multirow{8}{*}{ 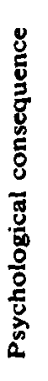 } & Motivation & Achievement need & Affiliation need \\
\hline & Locus of control & Internal & External \\
\hline & Cognitive style & Field independent (analytic) & Field dependent (global) \\
\hline & Uncertainty orientation & Tolerates ambiguity & Intolerant of ambiguity \\
\hline & Risk taking & $\begin{array}{l}\text { Willing to take calculated 'entrepreneurial' } \\
\text { risks and to show initiative }\end{array}$ & Unwilling to take any risks, conservative \\
\hline & Interpersonal relations & Opportunist, exploitive competitive & Communalist, co-operative \\
\hline & Time & Linear, from past to future & Circular, based on seasons \\
\hline & Relation to authority & Autonomous, independent & Dependent, conforming \\
\hline
\end{tabular}

by the 'other-culturedness' of many blacks - by training in job-related skills, in social skills of deportment, etiquette and dress, as well as in such areas as self-assertiveness and in achievement motivation. The Anglo-American Corporation $/ \mathrm{JCl}$ 'cadet scheme' is based on similar premises. While it is probable that most individuals can benefit from these kinds of development programmes, the approach just described is aimed primarily at fitting the individual into some predetermined job system. Of this approach, Kingsley notes the following misgivings:

This [selection] approach may indeed pay off in terms of reducing training 'wastage' . . . at least in the short run. But South Africa, which has one of the most highly developed programmes of African personnel assessment and selection, probably epitomises the exploitative social conditions and assumptions to which this approach may be tied in developing countries, i.e. an economy in which the industrial sector is an exclusive and largely foreign preserve $v i s-\grave{a}$-vis the majority of the population, who are regarded as a pool or reserve of surplus labour from which to draw only the 'best' for employment. ${ }^{17}$

and further that

It [selection and training] tends to short-circuit the process of modifying and adapting the institutional structure and job designs of industrial work to local needs and conditions. Rather than opening the possibility that industrial wol $k$ could be re-designed to better fit potential workers, the selection emphasis incorporates a tendency to view the nature of industrial work as given and to search out [or create by training] those individuals who will most easily fit into it. ${ }^{18}$ (emphasis added)
Moreover, as Onyemelukwe ${ }^{19}$ points out, this approach requires the individual to suppress and set at nought the abilities and values he already possesses before he is able to acquire the more 'desirable' characteristics demanded. In other words, the person first has to 'unlearn' what he already knows before he can be taught anything further. This is not only a very difficult thing to accomplish, as the individual tends to revert to earlier modes of thought and behaviour under stress, as has been shown above, but it also denies rather than utilizes the individual's own 'natural resources'.

The second approach to increasing the degree of match between the individual and his environment is to alter or restructure the environment so that it fits more closely the specific needs and values of the person. Where the first strategy was aimed broadly at 'fitting the man to the job', this second approach emphasizes the need for 'fitting the job to the man', for as Cherniss notes 'It is easier to restructure a role than to restructure the character of either an individual or a society'. ${ }^{20}$ In accordance with this argument, and in order to build upon the individual's existing values and abilities rather than deny them, it is argued that attention should be given to the development of organizational and management structures that are more culturally appropriate. In a similar spirit, Nattrass states the following: -... before one commits oneself wholly to a program to re-orient black values, surely one would be wise to ask whether or not there are values in the black value system that might prove to be highly functional to the private enterprise system if the latter was slightly adapted to meet them. Is there not perhaps a way in which a number of values highly regarded in black communities could be incorporated into the private enterprise system to the mutual benefit of both?'21 
She then goes on to suggest the use of consensus decisionmaking rather than the systems more generally used in South Africa such as hierarchical or majority vote systems. While she concedes that consensus decision-making costs are high, both in terms of the number of people involved and the longer duration of the decision-making process, she argues that once the consensus has been reached the advantages are substantial. She states 'There is a greater chance that the decision is correct, as a larger number of people have been involved in the assessment process and further, because all the parties to the final decision are committed to it, there is a far greater chance that it will be purposefully implemented. ${ }^{22}$

\section{Some examples of organizational restructuring}

The balance of this paper will examine additional ways in which this same kind of 'slight adaptation' could be made to the dominant organization value system in an attempt to make it more compatible with the black value system, as described above and elsewhere. ${ }^{23}$ This approach, says Nattrass 'has as much to offer, in terms of increased efficiency, as the present efforts to re-orient black values to those currently accepted in the market economy. ${ }^{24}$ The following three approaches to the problem will be organized around three of the major 'problems' that were seen (Table 1) to arise with the use of traditional Third World labour.

\section{Problem one: Collectivism vs individualism}

As we have seen, this aspect of social structure is perhaps the single most important dimension differentiating between 'modern' and 'traditional' cultures and from which is seen to flow a host of other 'evils' such as lack of initiative, social conformity, unwillingness to take reasonable risks, etc. The solution to this problem has generally been one of attempting to change the individual's attitude to accept a more individualistic outlook by stressing the need to achieve positions of power and status and their accompanying material benefits.

An alternative to this approach is suggested by Gavin who, in looking at the mental health of US workers, discusses the need for 'collaborative and non-competitive work strategies as our US society reaches the constructive limits on an individualistic achievement mode' ${ }^{25} \mathrm{He}$ then offers the following as possible counter-measures to the deteriorating mental health situation:

(i) 'team development processes which foster the view of (executive) groups as co-operative family units', and

(ii) 'structural changes using non-traditional patterns of authority (for example matrix structures, project management), employee scheduling of work (split jobs, flexible hours) and work design where requirements are dictated as much by human needs as by task considerations. ${ }^{26}$ (See footnote b on p.190)

An example of how this kind of environmental restructuring can be accomplished with a simultaneous increase in cost effectiveness appears in a study by Emery and Trist. ${ }^{27}$

Quoting data from Trist and Murray, ${ }^{28}$ Emery and Trist show the effects of two very different forms of work force organization in a British deep-seam coal mining operation.
In the study, using the same technology and working on similar coal faces, the only variable to differ was the organization of the work force, one using a standard industry-wide approach (designated the 'conventional' system), the other using a work-team or 'composite' organization. The conventional system combined a complex formal structure with simple work roles; the composite system combined a simple formal structure with complex work roles. In the former, the miner has a commitment to only a single part task and enters into only a very limited number of unvarying social relations that are sharply divided between those within his particular task group and those which are 'outside'. With those people 'outside', he shares no sense of belongingness and he recognizes no responsibility to them for the consequences of his actions. In the composite system, the miner has a commitment to the whole task group in co-operation with members of the total group; he may be drawn into any task on the coal face with any member of the total group in a kind of matrix job structure. A comparison of the organizational structure and productivity of the two systems is given in Table 2 .

Table 2 The effects of a change in labour force organization on productivity and absenteeism in the same work force, working on the same job, with the same technology (adapted from Emery and Trist ${ }^{23}$

\begin{tabular}{llrr}
\hline & & Old & New \\
\hline \multirow{2}{*}{$\begin{array}{llr}\text { Number of men } \\
\text { organization force }\end{array}$} & Number of separate tasks & 41,0 & 41,0 \\
& Mean job variety: & 14,0 & 1,0 \\
& Task groups worked with & 1,0 & 5,5 \\
& Main tasks worked & 1,0 & 3,6 \\
& Production & \\
& Percent of shifts behind schedule & 69,0 & 5,0 \\
Productivity & Number of consecutive weeks & & \\
& without loss in cycle & 12,0 & 65,0 \\
and & Absenteeism as a percentage of & & \\
& possible shifts: & & \\
absenteeism & Without reason & 4,3 & 0,4 \\
& Sickness and other & 8,9 & 4,6 \\
& Accidents & 6,8 & 3,2 \\
& Total & 20,0 & 8,2 \\
\hline
\end{tabular}

Average percent of coal recovered for each daily cut, corrected for differences in seam transport

Therefore it would appear that a reorganization of this coal mining work force along the lines suggested by Gavin $^{29}$ resulted in greater levels of satisfaction and improved productivity and profitability in terms of several of the most commonly used indices - output, downtime, accidents and absenteeism. If these results could be achieved with British coal miners, there is no reason why similar results could not be achieved by instituting analogous forms of job restructuring with a group of black South African workers. (For details of this study and similar findings in the Indian textile industry, as well as information about the basis for forming such work groups, see Emery and Trist, ${ }^{27}$ particularly pp.47-52.) 
It would appear, from this example at least, that restructuring of the work environment to meet the needs of the local work force can have positive rather than negative implications for both individual and organization, and that in place of attempting to 're-educate' Third World workers into individualistic modes of behaviour, their group orientation can be capitalized on and 'harnessed' by appropriate organizational design - in this case by the use of the work group.

Problem two: Need for affiliation vs need for achievement

Growing out of the distinction between group $v s$ individual orientation is the motivational distinction emphasized by, inter alia, McClelland ${ }^{30,31}$ between the need for achievement and the need for affiliation. McClelland points out that countries with high levels of technology and high levels of economic growth are those whose populations are characterized by relatively high levels of achievement need, whereas those countries with low levels of technological sophistication and low economic growth rates are generally high in affiliation need and low in achievement need. Thus the dichotomy between achievement and affiliation need overlaps to a large extent with the developed/underdeveloped and modern/traditional dichotomies already discussed. A consequence of McClelland's argument is that a number of programmes aimed at teaching need for achievement to Third World countries have been devised and instituted with some modicum of success. ${ }^{32}$

However, here again the approach has been one of denying indigenous values instead of finding means by which the environment could be restructured to utilize or 'harness' them.

A way in which this could be achieved is suggested by Van den Berg in the context of a new perspective on black education in South Africa. He points to the successes of the Japanese system in its technological development, despite its collectivist tradition and heavy stress on conformity. He notes that

It should be pointed out that Western educationists have tended to believe that conformity to group wishes impaired the intellectual development of the individual. However, if it is considered to what extent the Japanese traditions of group conformity have been utilized to stimulate the phenomenal education and technological development in Japan, then it becomes clear that the above assumption is incorrect and that the Black man's traditions of conformity can similarly be utilized. The early Soviet educational system is a further example of group orientation being successfully developed in the education system. ${ }^{33}$

Van den Berg then goes on to describe four ways in which this group orientation can be utilized in an education system that is appropriate to the needs and values of the African social system.

(a) Firstly he suggests the subdivision of the class into subgroups based on criteria other than ability. Each group chooses its own leader and all competitiveness and evaluation occurs between the groups and seldom between individuals. He quotes Bronfenbrenner: 'Since each child's status depends in part on the standing of the collective of which he is a member, it is to each child's enlightened self-interest to watch over his neighbour, encourage the other's good performance and help him when he is in difficulty'. ${ }^{34}$

(b) Class-room groups should be relatively permanent in nature, as this approximates the peer group orientation of the black's socialization practice ( $c f$. Dreyer ${ }^{35}$ ). Furthermore, such relative permanence of the group ensures a group identity and cohesion that makes group prestige something to be strived for.

(c) The early Soviet system had a system of 'adoption' in which senior classes would 'adopt' or take responsibility for the performance of a junior class. Furthermore, this responsibility would carry beyond the formal school setting and result in assistance being given to the junior class members outside the classroom context.

(d) Finally, control and discipline is exercised by the group over those members who are not contributing adequately to the group's performance. As a result the individual's conformity to the group is utilized for the group's overall objectives (see Van den Berg ${ }^{36}$ ).

The implications of Van den Berg's thesis for the argument presented here is that a restructuring of jobs with black African workers ought to take place along the lines of work group formation in which the performance of the group, rather than that of the individual, is being evaluated. This argument also coincides with that of Lewis, ${ }^{37}$ who, in looking at theories of reward and remuneration, identifies four basic assumptions about the nature of man, one of which he terms Social Man. According to this view, the individual's performance is governed as much by social factors as by monetary ones (as shown by the Hawthorne studies and the relative strength of the social needs in Maslow's Need Hierarchy). In terms of this social view of man, group processes such as conformity and the affiliation need should be used to motivate performance, and the level of remuneration should be based on group rather than individual performance, certainly at the bonus level. The use of this approach ensures, on the one hand, the individual's affiliation and other social needs are met, while, at the same time, the achievement need of the organization is also met by competition between work groups. In addition, the group provides mutual support to the group members and assists them in coping with stress and with the acquisition of new skills while it also initiates its own disciplinary procedures. In line with Van den Berg's ${ }^{38}$ recommendation, the work group ought to be relatively stable so as to lead to identification of members with the group. Furthermore, it should be relatively autonomous: for example, having a say in who is admitted to its ranks; how the group bonus should be allocated to the members and so on; thus giving group members a sense of participation in the work arrangements.

Finally, the concept of the work group need not be limited to the lower work levels, but can be utilized almost across the board. This ties in with Gavin's view of executive groups as 'co-operative family units' ${ }^{39}$ One can quite easily imagine a situation in which a departmental head or manager has two or three subordinates all competing with each other and with the departmental head for the latter's favour and 
ultimately for his position. By a simple restructuring, such a 1-2 hierarchy could be converted into a three man team of equals, providing an extension of skills by making use of hitherto un(der)utilized skills and creating opportunities for mutual support in a co-operative rather than competitive work environment. Furthermore, such a move would serve to flatten the organizational hierarchy by the removal of the one level. Gavin, inter alia, has shown that tall organizational structures tend to generate more symptoms of mental ill health and other 'psychological hazards' than do flat structures. ${ }^{40}$

\section{Problem three: Linear vs circular conceptions of time} We have discussed elsewhere ${ }^{41}$ this distinction between a linear conception of time (in which time is seen to extend from the infinite past through the present to the infinite future) and a circular conception of time (where time is bound to seasonal phenomena and is such that opportunities are never lost, but merely delayed until the following cycle). It was argued that the former mode of time perception was typical of Western man while the latter is typical of Chinese and African cultures. Finally the implications of these different forms of time perception for punctuality, the planning process and the meeting of deadlines were discussed. This paper focusses on another related issue - that of absenteeism - and suggests a possible solution on the basis of a relatively minor organizational restructuring.

Absenteeism is of course a major problem for management in Third World countries and arises for a number of reasons, including a lack of commitment to the idea that time is expensive and not to be wasted. Another reason is the fact that the labour force is relatively close to a subsistence economy and work is often undertaken only until such time as the coffers are full enough to sustain the household. Work is thus often seen as a means to an end and not as an end in itself as is the case with the so-called Protestant work ethic. Finally the extended family requires the observance of a large number of ceremonial occasions such as weddings, funerals, initiations and the like. For these and similar reasons absenteeism is an important factor in the economies of developing countries.

A novel approach to this problem is given by Arbose ${ }^{42}$ when he describes a study by Thorsrud ${ }^{43}$ in a New Dehli post office. Faced with high levels of absenteeism and constrained by the need for labour-intensive work systems, the authorities approached the problem by accepting the unavoidability of absenteeism, formalizing it and incorporating it into a system of 'free time'. The essence of the design strategy was a matrix job design that ensured that several people could do each job and that each person could do several jobs reasonably well. This resulted in there always being someone present to fulfil the various task requirements. The second aspect of the job redesign was to move to a piece-work basis so that work in addition to a basic minimum was paid on a 'bonus' system. Thus instead of being paid to be at work (even when productivity was zero) the new system paid workers only for work done. Because of the overlapping competencies, individual workers were able to negotiate with their colleagues to ensure that their particular duties were performed even when they themselves were not present. The result of these changes was to increase productivity because the 'workers are doing more work in less time while earning the same rates of pay'. ${ }^{4}$ In addition the workers now had more time to attend to their own businesses and outside interests, such as small scale farming, part-time jobs, etc. In this way the post office workers were able to enhance their own economic situations and the national economy, while still fulfilling their obligations to the postal authorities. By reorganizing itself and by moving from a system of guaging productivity by counting bodies present to a system of guaging amount of work done, the post office was able to improve its own efficiency and productivity and this was achieved by rewarding workers with the free time created by their own improved efficiency.

Moreover, Thorsrud argues that this kind of general principle can be applied to large modern manufacturing plants. However, this would require a very flexible organization and the elimination of nearly all fixed working hours and many fixed jobs. This is not very different from the recent highly successful campaign by a leading commercial bank to man its suburban branches and agencies using part-time staff on very flexible hours involving each person for no more than a few hours on one or two days a week. The response was so large that the campaign was terminated after only one week.

Jobs would, of course, have to be organized on a matrix system with each worker having a major role and several secondary roles. Thorsrud argues that except for a core of full-time workers, this flexitime job-sharing approach can extend right through to middle and top management. Such an arrangement, he argues, would also help to prevent the staff burn-out that occurs at these levels by making it possible for managers to move into and out of these pressure areas. Thus while each manager could have an area of primary responsibility, it would also be possible to shift him into a special task force for a short period ( $3-6$ months) to tackle specific prblems or projects before returning him, with his batteries recharged, to the mainstream of his activities. Furthermore, no plant or organization ever has had to close down when its senior staff go on leave, provided of course this is properly scheduled. Given modern computing facilities, there is no reason why even a fairly sophisticated organization of 600 or more workers could not have a week by week or even daily scheduling of its complete work force.

The purpose of the three examples of alternative job designs given above is not to put them forward as blueprints for successful human resources utilization in South Africa. Rather it has been to show that alternative solutions to the problem of using Third World labour in a developed economy are possible, and to suggest that the current emphasis on 'fitting the man to the job' is not necessarily the most cost-effective approach. This is not meant to imply that management has no role to play in the personal growth and development of its workers - this remains an important managerial responsibility (see for example Kingsley ${ }^{45}$ ). More importantly, the organization stands to gain in both the short and long term by developing the abilities and skills it needs for its own growth and future profitability. 
However, particularly in Third World countries, this process of education and training must be accompanied by deliberate efforts to redefine jobs and organizational structures and to meet the values and needs of the indigenous population in a kind of cultural give and take. This has occurred, for example, in Japan with the introduction of quality control circles and is a good example of how profit maximizing organizations can operate successfully with a very different business orientation from that found in the conventional Western commercial enterprise. Essentially, quality control circles focus on inter-group rather than interpersonal competition and seek to engender higher levels of employee commitment to and involvement in the organization. ${ }^{46}$

The fact that the Japanese were the first to develop and implement quality circles in industry on a wide scale is no accident. Since Japan thrust itself into the industrial world and adopted the sophisticated technology required for this purpose, it has had to find ways of harnessing its workers' energies in the drive for industrial development that remain consistent with fundamental Japanese cultural paradigms. We maintain that, because of its analogous cultural system, South African industry would do better to follow the Japanese example than to slavishly imitate the Western business model. And we observe that, paradoxically, Western business organizations are themselves beginning to look more and more to Japan for answers to their business problems ${ }^{47}$ The problems of Western business organizations do not reside in their lack of technological sophistication, but largely in their poor management of worker relations. Hajima Karatsu puts it nicely, 'In Western business the super elite give play to their originality but workers at the lower levels are simply made to do standardized work on the basis of manuals . . . In Japan, however, it [quality control] has been changed into a movement for total elimination of inferior products through creative co-operation by all quarters concerned ... The quality control circles have revived an old spirit of craftsmanship in modern factories' ${ }^{48}$

This paper has attempted to show the possibilities in South Africa of restructuring managerial roles and preconceptions and of finding ways in which the job can be restructured to meet the needs of its non-Western labour force.

To conclude, a useful analogy can be found in biology for the process suggested in this paper. It is the distinction between parasitism and symbiosis. Symbiotic relationships exist when different organisms live in intimate association with each other, providing in the process a mutual advantage to both. Parasitic relationships occur when this advantage is undirectional and where one organism lives at the expense of the other. In terms of this analogy, the current imposition of Western industrial paradigms on an indigenous African world view can be regarded as a parasitic relationship in so far as the former uses the latter for its own ends and at the latter's expense. What we have tried to argue for in this paper is a move to a more symbiotic relationship in which adaptations are made on the part of both parties so that Western and African cutural paradigms can sustain and enrich each other in their mutual desire for growth and development, to the benefit of the individual, the organization and the national economy.

\section{References}

1. Coldwell, D.A.L. \& Moerdyk, A.P. Paradigms apart: Black managers in a white man's world. S.A. J. Bus. Manage., 1981, 12(3), pp.70-76.

2. Wober, M. Psychology in Africa. London: International African Institute, 1975.

3. LeVine, R.A. Patterns of personality in Africa. Ethos, 1973, 1(2), p.124.

4. Ibid., p.125.

5. Van den Berg. D.J. Black eduction - a new perspective on developing the potentialities of the black pupil. Humanitas $R S A, 1980,6(2), \mathrm{pp} .97-110$.

6. Safavi, F. A model of management in Africa. Acad. Manage. Rev., 1981, 6(2), pp.319-331.

7. Mackay, M. Aspects of upward occupational movement of Blacks, Part I: The identification of problems experienced by both upwardly mobile individuals and management. Johannesburg: NIPR (CSIR Special Report Pers 303), 1980, p.12.

8. (a) Backer, W. Motivating Black Workers. Johannesburg: McGraw-Hill, 1973.

(b) Becker, P. Tribe and Township. St Albans: Panther, 1974.

(c) Matsheke, M. Problems of communication between the races. Personnel Manage. (NDMF), March, 1972.

(d) Tiley, A.S. Bridging the Communication Gap between Black and White. Cape Town: Tafelberg, 1974.

(e) Verster, R. Communication with black workers - a systems approach. Bloemfontein, UOVS, Department of Industrial Psychology, Personnel Research Division, 1976, No $\mathrm{P} / 33$.

9. Van den Berg, D.J., op. cit., p.103.

10. Onyemelukwe, C.C. Men and Management in Contemporary Africa. London: Longman, 1973, p.7.

11. Isaacs, H.C. The meaning of cultural variations in child rearing practices. In Getty, C. \& Humphreys, W. (Eds.), Understanding the Family. New York: Appleton-Century-Crofts, 1981, p.31.

12. Gordon, A. \& Goduka, I.N. The identification of critical factors in the socialization process in an urban black community: current status of an empirical investigation, NIPR, 1981 (Unpublished document).

13. Berry, J.A. \& Amis, R.C. Acculturative stress: The role of ecology, culture and differentiation. J. Cross Cultural Psychol., $1974,5(4)$, pp. $382-406$.

14. LeVine, R.A., op. cit.

15. Van Harrison, R. Person-environment fit and job stress. In Cooper, C.C. \& Payne, R. (Eds.), Stress at work. New York: Wiley, 1978.

16. Sanford, N. The American College. New York: Wiley, 1962, p.727.

17. Kingsley, P. Technological development: Issues, roles and orientations for Social Psychology. Paper delivered at International Conference on Social Psychology and Developing Countries, University of Lancaster, Sept. 1980, p.28.

18. Ibid., pp. $28-29$

19. Onyemelukwe, C.C., op. cit.

20. Cherniss, C. Staff Burnout: Job Stress in the Human Services. London and Beverley Hills: Sage, 1980, p.158.

21. Nattrass, J. Problems and Impediments. In Breytenbach, W. (Ed.), Job Advancement in South Africa. Johannesburg: S.A. Foundation, 1980, p.32.

22. Ibid.

23. (a) Coldwell, D.A.L. \& Moerdyk, A.P., op. cit.

(b) LeVine, R.A., op. cit.

(c) Van den Berg, D.J., op. cit.

(d) Safari, F., op. cit.

(e) Hofstede, G. Cultures Consequences: International Dif-

ferences in Work Related Values. Beverley Hills: Sage, 1980.

24. Nattrass, J., op. cit., p.32.

25. Gavin, J.F. Occupational mental health - forces and trends. Personnel J., 1977, 56(4), p.200.

26. Ibid.

27. Emery, F.T. \& Twist, E.L. Socio-technical systems. In Frank, H.E. (Ed.), Organization Structuring. London: McGraw-Hill, 1971 . 
28. Trist, E.L. \& Murray, H. Work Organizations at the Coal Front. Tavistock Institute of Human Relations, Document No. $506,1948$.

29. Gavin, J.F., op. cit.

30. McClelland, D.C. The Achieving Society. Princeton N.J.: Van Nostrand, 1961.

31. McClelland, D.C. \& Winter, D.B. Motivating Economic Achievement. New York: Free Press, 1969.

32. Ibid.

33. Van den Berg, D.J., op. cit., p.106.

34. Bronfenbrenner, H. Two Worlds of Childhood: U.S.A. and U.S.S.R. London: George Allen and Unwin, 1971, p.50.

35. Dreyer, H.J. The Zulu Adolescent in Changing Society. University of Zululand, Paidonomia, 1975, 42), pp.73-74.

36. Van den Berg, D.J., op. cit., pp.106-107.
37. Lewis, W.M. The design of basic pay structures. Johannesburg: NIPR (CSIR Special Report Pers 315), 1980.

38. Van den Berg, D.J., op. cit.

39. Gavin, J.F., op. cit., p.200.

40. Ibid., p.200.

41. Coldwell, D.A.L. \& Moerdyk, A.P., op. cit.

42. Arbose, I.R. Giving absenteeism the stamp of approval. Int. Manage., 1981, 36(1), pp.29-31.

43. Thorsrud, E. Cited in Arbose, I.R. Ibid., p.31.

44. Ibid., p.30.

45. Kingley, P., op. cit.

46. Collard, R. The Quality Circle in context. Personnel Manage., (London), 1981, 13(9), pp.26-59.

47. See for example Organizational Dynamics, 1981, 9(4), pp. $36-43$.

48. Karatsu, H. Cited in Collard, R. Ibid., p.30. 